\title{
Synthesis and characterization of wollastonite-2M by using a diatomite precursor
}

\author{
Daniela Novembre ${ }^{1, *}$, Carla Pace ${ }^{1}$ and Domingo Gimeno ${ }^{2}$ \\ 1 Dipartimento di Ingegneria e Geologia, Università G. D’Annunzio, Chieti Scalo, 66100, Italy \\ 2 Departament de Geoquímica, Petrologìa i Prospecció Geològica, Facultat de Geologia, Universitat de Barcelona, \\ 08028, Spain
}

[Received 18 November 2015; Accepted 18 April 2017; Associate Editor: Karen Hudson-Edwards]

\section{ABSTRACT}

Solid phase reaction synthesis of wollastonite- $2 M$ by a natural rock precursor as the source of amorphous silica and $\mathrm{CaCO}_{3}$ is reported. Chemical treatments were carried out on a diatomitic rock from Crotone (Calabria, Italy) in order to measure its reactive silica and $\mathrm{CaCO}_{3}$ contents. Four series of synthesis were performed at $1000^{\circ} \mathrm{C}$ at ambient pressure by mixing, at different stoichiometry, the diatomitic rock with a natural limestone as a source of additive $\mathrm{CaCO}_{3}$, and sodium carbonate $\left(\mathrm{Na}_{2} \mathrm{CO}_{3}\right)$ as triggering agent.

Wollastonite- $2 M$ was characterized by chemo-physical, crystallographical and morphological-microtextural analyses. All these characterizations, together with infrared and nuclear magnetic resonance $\left({ }^{29} \mathrm{Si}\right)$ responses provide values comparable to literature data. Estimation of the amorphous phase in the synthesis powders was performed through quantitative phase analysis using the combined Rietveld and reference intensity ratio methods, resulting in a final product of $96.3 \%$ wollastonite- $2 M$.

KeYWords: diatomite, calcium silicates, wollastonite- $2 M$.

\section{Introduction}

THE calcium silicate wollastonite $\left(\mathrm{CaSiO}_{3}\right)$ is a common mineral in metamorphic and metasomatic (skarn) rocks (Deer et al., 1978) produced in most of cases by the devolatization of an impure limestone precursor. Typically, calcite reacts with silicic magma, even-laminated chert intercalated in carbonate rocks or quartz detrital impurities in limestone in the course of a prograding regional (MacKinnon, 1990) or thermal metamorphism to form wollastonite and $\mathrm{CO}_{2}$ that escapes from the rock system. In fact, $\mathrm{CO}_{2}$ escaping from the rocks (open system) is critical to favour an efficient crystallization process in order to reach a deposit of economic size of this mineral, as a low (or alternatively, water-diluted) partial pressure of $\mathrm{CO}_{2}$ favours the crystallization of wollastonite and a difficult reversibility of the reaction. This

*E-mail:dnovembre@unich.it

https://doi.org/10.1180/minmag.2017.081.025 need of a relatively natural open system is explained in local geological terms (and associated mineral deposit prospecting criteria) in the way that a major fault or structure close to the deposit is needed as a means of a pathway of conduit to deplete the system of $\mathrm{CO}_{2}$ (Beisswenger, 1996).

Other natural (non-economic) occurrences of wollastonite have been reported: in marble enclaves reacting with the melt sheet of an impact crater, a very unusual type (Rosa, 2004); in a number of volcanic sites as pyrometamorphic products of enclaves captured by erupting magmas close to the earth surface, or directly on it (see e.g. Lacroix, 1893; Sabine and Young, 1975; Barker and Black, 1980); and as product of mixing of silicate and carbonate magmas (Dawson et al., 1992).

Wollastonite synthesis is of twofold interest: in the petrogenesis of metamorphic rocks and in industry. In fact, most metamorphic petrology manuals contain $P$ - $T$ wollastonite synthesis diagrams, but very strikingly not always coincident, especially in the low-temperature field. A review of the literature shows that attempts to build such a 
diagram have been ongoing for more than a century, both in a theoretical and empirical way, and that all the references currently used lie in the work by Harker and Tuttle (1956) (see references therein). On the other hand, industrial interest (focused on Portland cement clinker and ceramic industries) has led to the creation of the lime-silica phase diagram (Rankin and Wright, 1915, mainly improved by redefinition of the thermal limits of phase transition by Welch and Gutt, 1959).

Most of the described cases involving the reactions of magma-limestone enclaves are related to basaltic magma. In some cases, like the Somma-Vesuvius volcanic system, reacted large limestone fragments occur as xenolithic nuclei of large volcanic bombs, both massive or geodic-drusic (Lacroix, 1893) holding centimetre-sized wollastonite crystals (and a large number of other calc-silicatic minerals). The initial purpose of this experimental work was to explore the mechanisms and timing of wollastonite formation under these conditions (high-temperature and low-pressure range of synthesis), in order to interpret how fast these enclaves might grow when occurring within shallow intrusions of basic magma bodies in extruding magma. The well-known process of other calcosilicate formation associated with wollastonite is not considered here.

In general, $\mathrm{CaSiO}_{3}$ is present in two structurally quite different forms (Hesse, 1984): the phase stable above $\sim 1150^{\circ} \mathrm{C}$ called pseudowollastonite or $\alpha$-wollastonite; and the phase stable below $1150^{\circ} \mathrm{C}$ called $\beta$-wollastonite or wollastonite. A number of polytypes of $\alpha$-wollastonite have been recognized and described (Yamanaka and Mori, 1981); regarding $\beta$-wollastonite, the polytypes are distinguished by the symbols $\mathrm{n} T$ and $\mathrm{n} M$, where $T$ and $M$ stand for triclinic and monoclinic symmetry and $n$ indicates the number of subcells with $d$ subcell $(100) \approx 7.7 \AA$. The polytype $2 M$ is commonly called 'parawollastonite'.

Wollastonite is characterized by an acicular crystal shape, whiteness and fluxing properties; these properties lead to its applications in the fields of tile, paint, paper and vinyl tile manufacture. Ceramics based on wollastonite, for example, are characterized by several advantages: low linear thermal expansion coefficient; high strength; low thermal conductivity; and non-wettability with aluminium melts (Pavlov et al., 2008). In compositions of paints, the needle-laminar shape of wollastonite crystals improves the coverage and strength parameters of coatings and allows for substantial savings in the amount of pigments required (Nikonova et al., 2003). When wollastonite is used in lining in metallurgy, it facilitates fast oxidation of aluminium and the formation of an aluminium oxide film preventing further reaction between wollastonite ceramics and metal melt (Demidenko and Konkina, 2003). Wollastonite is also a candidate material for high frequency insulators owing to its low dielectric loss at high frequency (Lin et al., 2006). It is also used as a substitute for asbestos in certain situations, as it has not been found to cause any health risks (Nikonova et al., 2003; Teir et al., 2005; Gladun et al., 2007), e.g. replacing potentially hazardous asbestos in automotive brake pads (Justness, 2012). Recently, wollastonite ceramics have been studied as bioactive materials for orthopaedic applications and used to improve the mechanical properties of the biopolymers because of its good bioactivity and biocompatibility (Hench, 1991; Lin et al., 2006).

The world production of wollastonite is $\sim 600,000$ tonnes and is largely dominated by China (300-350,000 tonnes), followed by India (100-130,000 tonnes) and the USA (Brown et al., 2011), with minor productions in Mexico, Finland and Spain.

As far as synthesis of wollastonite is concerned, experimental procedures refer to the phase reaction method (Kurczyk and Wuhrer, 1971; Kridelbaugh, 1973; Kurczyk, 1977; Kotsis and Balogh, 1989; Ibañez et al., 1990; Grigoryan et al., 2010), the hydrothermal process (Glasser and Taylor, 1978; Grigoryan et al., 2006, 2008, 2010), the glass ceramic method (Philip and Binet, 1971), the solgel method (Villegas and Fernandez Navarro, 1988); the molten salts technique (Trubnikov et al., 1989); the microwave method (Vichaphund et al., 2011) and the hydrothermal microemulsion method (Lin et al., 2006).

Kridelbaugh (1973) studied the kinetics of the reaction calcite $_{(\mathrm{s})}+$ quartz $_{(\mathrm{s})}=$ wollastonite $_{(\mathrm{s})}+$

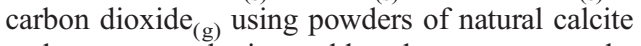
and quartz employing cold-seal pressure vessels. Temperature, pressure and grain size were varied to determine their effects upon reaction rate (temperature ranged from 800 to $950^{\circ} \mathrm{C}$, pressure varied from 1000 to $25,000 \mathrm{psi}$ and grain size ranged from 10 to $70 \mu \mathrm{m})$. Predictably, higher temperatures and finer sizes favoured reaction rates, while variation in pressure produced erratic behaviour. The author explains that in a dry system nucleation of wollastonite occurs on the quartz grains, while in a fluid phase of $\mathrm{CO}_{2}$ and $\mathrm{H}_{2} \mathrm{O}$, wollastonite forms on calcite fragments. The activation energy for the reaction $\mathrm{CaCO}_{3}+\mathrm{SiO}_{2}=\mathrm{CaSiO}_{3}+\mathrm{CO}_{2}$ is between 25.5 and $29 \mathrm{kcal} / \mathrm{mol}$ and the rate equation is of 
parabolic form $X=\mathrm{k} t^{n}$, where $X$ is the percent reaction, $\mathrm{k}$ the rate constant, $t$ the time and $n$ the order of the reaction.

With regard to the solid-state method, Bryden et al. (1992) and Ibañez and Sandoval (1993) pointed out that, when mixing silica and lime raw materials of natural and technogenic occurrences in a wide range of compositions, the first phase identified is a $\beta$-calcic orthosilicate; it is a thermodynamically unstable phase that, for molar compositions $\mathrm{CaO} / \mathrm{SiO}_{2}=1$, transforms into wollastonite according to the diagram of Welch and Gutt (1959).

In the past a lot of natural silica-containing materials have been applied in the synthesis of wollastonite: $\mathrm{SiO}_{2}$ smokes (Kotsis and Balogh, 1989; Nour et al., 2008); silica sources characterized by high specific surface; silica gel or amorphous materials such as opal or diatomites (Grigoryan et al., 2008); or gaizes (Grigoryan et al., 2010). In particular, Grigoryan et al. (2008) report on the synthesis of calcium hydromonosilicate from diatomite under hydrothermal conditions $\left(150^{\circ} \mathrm{C}\right)$ and its transformation into wollastonite $(\alpha+\beta)$ at $1150^{\circ} \mathrm{C}$. Grigoryan et al. (2010) report on the synthesis of $\beta$-wollastonite by using a natural source of amorphous silica and $\mathrm{CaO}$ (a Lithuanian gaize) with different methods, i.e. a phase reaction method, a hydrothermal one and a cogranulated technique. In particular, with the phase reaction method the gaize was mixed to calcium carbonate (providing a $\mathrm{CaO} / \mathrm{SiO}_{2}$ molar ratio of 0.95 ) in the presence of $\mathrm{Na}_{2} \mathrm{CO}_{3}$ mineralizer; the mixture was placed in alumina crucibles and exposed for two hours in a furnace at a temperature of $1000^{\circ} \mathrm{C}$. The synthesized product reveals an X-ray pattern characteristic of $\beta$-wollastonite associated with a phase indicated as $\beta-(\mathrm{CaO})_{2} \mathrm{SiO}$ (probably a $\beta$-dicalcic-silicate). However, it should be noted that a very poor characterization of the synthesized products is provided, only establishing the density of the resulting product as $2.7382 \mathrm{~g} / \mathrm{cm}^{3}$ and not reporting the X-ray pattern but only the $d / n$ values. The synthesized powders are, in effect, polymineralic, as they contain $\beta$-wollastonite associated with the other phase $\beta-(\mathrm{CaO})_{2} \mathrm{SiO}$; moreover the absence of unreacted phases and/or amorphous components cannot be excluded.

The scope of this work is to synthesize monomineralic powders only constituted by wollastonite- $2 M$ by the using a natural source of amorphous silica and $\mathrm{CaO}$ that has never been used previously with the solid state method, i.e. a diatomitic rock from Crotone, Italy. Systematic samplings during the experimental run enable the progress in the crystallization of the mineral to be followed and allows the time at which the climax in the crystallization is reached to be obtained due to the absence of other phases. Complementary characterizations (calculation of the density, specific surface, Rietveld structure refinement, morphological analysis, infrared and nuclear magnetic resonance analyses) together with an estimation of the amorphous phase and unreacted $\mathrm{CaO}$ in the synthesis powders will represent a complete spectrum of characterization of the synthesized mineral. Furthermore, a discussion on the geological significance of the achieved synthesis is provided, giving special attention to the pyrometamorphic processes related to active volcanism.

\section{Experimental}

\section{Methods}

Diatomitic rock finely ground (particle size $<60 \mu \mathrm{m}$ ) and products of synthesis were analysed by powder X-ray diffraction (PXRD) on a Siemens D5000 diffractometer operating with BraggBrentano geometry; $\mathrm{Cu} K \alpha=1.518 \AA, 40 \mathrm{kV}$, $40 \mathrm{~mA}, 2-45^{\circ}, 2-90^{\circ} 2 \theta$ scanning interval, step size $0.020^{\circ} 2 \theta$ ). Identification of phases and relative peak assignment were performed with reference to the following JCPDS codes (powder diffraction files from the International Centre for Diffraction Data, http://www.icdd.com/): 00-043-1460 for wollastonite-2M; 00-043-1001 for $\mathrm{CaO}$; 00-0160152 for cristobalite and 00-033-0302 for larnite.

Both the crystalline and amorphous phases in the synthesis powders were estimated using quantitative phase analysis (QPA) applying the combined Rietveld and reference intensity ratio (RIR) methods; corundum NIST 676a was added to each sample, amounting to $10 \%$ (according to the strategy proposed by Gualtieri, 2000), and the powder mixtures were homogenized by hand-grinding in an agate mortar. Data for the QPA refinement were collected in the angular range $5-120^{\circ} 2 \theta$ with steps of $0.02^{\circ}$ and $10 \mathrm{~s} \mathrm{step}^{-1}$, a divergence slit of $0.5^{\circ}$ and a receiving slit of $0.1 \mathrm{~mm}$.

Data were processed with the GSAS software (Larson and Von Dreele, 2004) and the graphical interface EXPGUI (Toby, 2001) starting with the structural models proposed by Hesse (1984) for wollastonite- $2 M$. The following parameters were refined: background parameters, zero shift, cell parameters and peak profiles.

Morphological analyses were obtained by means of scanning electron microscopy (JEOL JSM-840 
served by a LINK Microanalysis EDS system, with operating conditions of $15 \mathrm{kV}$ and window conditions ranging from 18 to $22 \mathrm{~mm}$ ) (Ruggieri et al., 2011).

Induced coupled plasma optical emission spectroscopy (ICP-OES, Perkin Elmer Optima 3200 RL) was performed on synthesized powders, which were prepared by fusion (Pt meltpot) in lithium meta-tetra borate pearls and subsequent acid solubilization and analytical determination following the procedure as explained in Fernandez-Turiel et al. (2003).

Wollastonite- $2 M$ density was calculated by He-picnometry using an AccuPyc 1330 pycnometer. The specific surface and porosity were obtained by applying the BET (Brunauer-Emmett-Teller) method with $\mathrm{N}_{2}$ using a Micromeritics ASAP2010 instrument (operating from 10 to $127 \mathrm{kPa}$ ), following the procedure as explained in Ruggieri et al. (2010).

The infrared analysis was performed with a spectrometer FTLA2000, served by a separator of $\mathrm{KBr}$ and a DTGS detector; the source of infrared radiation was a $\mathrm{SiC}$ (Globar) filament. Samples were treated according the method of Novembre et al. (2011) using powder-pressed pellets $(\mathrm{KBr} / \mathrm{sample}$ ratio of $1 / 100$, pressure undergone prior to determination of $15 \mathrm{t} / \mathrm{cm}^{2}$ ); spectra were processed with the program GRAMS-Al (GRAMS/AI TM Spectroscopy Software, Thermo Scientific Company).

${ }^{29} \mathrm{Si}$ magic angle spinning nuclear magnetic resonance $\left({ }^{29} \mathrm{Si}\right.$ MAS NMR) spectra were recorded using a BRUKER AVANCE-SPECTROSPIN spectrometer (7.05 Tesla). Spectra were processed by the program Bruker XWINNMR. A $90^{\circ}$ excitation pulse $(8 \mu \mathrm{s})$ and a $5 \mathrm{~s}$ relaxation delay were used to collect a variable number of scans (from 100 to 400 ) at $4000 \mathrm{~Hz}$ of rotation speed in a $7 \mathrm{~mm}$ zirconia rotor. The $29 \mathrm{Si}$ chemical shifts were referenced to 3-(trimethylsilyl)-2,2,3,3-tetradeutero propionic acid (sodium salt).

\section{Siliceous raw material: the 'Tripoli rock'}

The diatomitic rock utilized here is a siliceous rock cropping out in the Crotone Basin, in Southern Italy. According to Novembre et al. $(2004,2014)$ PXRD analysis reveals a general mineralogical composition of amorphous opaline silica, with quartz, montmorillonite, chlorite, kaolinite, 'K-micas' and minor carbonate minerals. A vertical and lateral variability in the chemistry of the deposit is observed; calcimetric (volumetric) analysis reveals that the sample used here has a mean value of $10 \%$ in $\mathrm{CaCO}_{3}$. Following the method proposed by Novembre et al. (2004), i.e. acid solubilization ( $\mathrm{HCl} 36-37 \%)$ and successive attack with $\mathrm{NaOH}(3 \mathrm{M})$, the final composition for 'Tripoli' was: $10 \mathrm{wt} . \%$ carbonate minerals; 22 wt.\% insoluble fraction (clay minerals and quartz); and $68 \mathrm{wt} . \%$ opaline silica.

\section{Synthesis}

Three series of synthesis were performed, characterized by different stoichiometry, i.e. a fixed amount of Tripoli was mixed with variable amounts of $\mathrm{CaCO}_{3}$ (sample L3 from Ruggieri et al., 2008) and sodium carbonate $\left(\mathrm{Na}_{2} \mathrm{CO}_{3}\right)$ was added as a triggering agent (Table 1). A fourth experiment was performed without sodium carbonate. The mixtures, finely ground and powdered, were heated inside alumina crucibles at $1000^{\circ} \mathrm{C}$ and at ambient pressure for two hours.

Synthesis products were sampled periodically and a loss of weight of the open crucible was observed and attributed to $\mathrm{CO}_{2}$ diffusion through the granular material (Novembre et al., 2010a,b; Pasculli and Novembre, 2012).

\section{Results and discussion}

\section{Mineralogical and chemical characterization of synthetic products}

Results of PXRD analyses performed on the three synthesis runs are illustrated in Figs 1, 2 and 3 while the mineralogical assemblages for each synthesis run are reported in Table 1.

In synthesis run 1 (Fig. 1) the crystallization of wollastonite- $2 M$, formerly associated to that of 'meta-cristobolite', unreacted calcium oxide and larnite, is evident in the time interval $0.5-1.5 \mathrm{~h}$; the situation does not change substantially with time, except for the disappearance of 'meta-cristobolite', visible in the spectrum at $2 \mathrm{~h}$.

In synthesis run 2 (Fig. 2) the crystallization of wollastonite- $2 M$ is associated with 'meta-cristobolite', unreacted calcium oxide, larnite and quartz (contained in the starting Tripoli rock) in the time interval $0.5-1 \mathrm{~h}$; longer synthesis periods led to the disappearance of larnite and $\mathrm{CaO}$ thus resulting in 'parawollastonite' plus 'meta-cristobolite' in the time interval $1.5-2 \mathrm{~h}$.

In synthesis run 3 (Fig. 3) wollastonite-2 $M$ is associated with: calcium oxide, larnite and quartz at $0.5 \mathrm{~h}$; the appearance of 'meta-cristobolite' at $1 \mathrm{~h}$; and in the time interval $1.5-2 \mathrm{~h}$ the disappearance 
TABLE 1. Starting mixture weights, molar compositions and relative obtained mineralogical assemblages for experimental runs.

\begin{tabular}{|c|c|c|c|}
\hline $\begin{array}{l}\text { Synthesis } \\
\text { run }\end{array}$ & Starting mixture & Moles & Mineralogical assemblage \\
\hline 1 & $\begin{array}{l}\text { 3.000 g Tripoli }+5.000 \mathrm{~g} \mathrm{CaCO}_{3}+ \\
0.128 \mathrm{~g} \mathrm{Na}_{2} \mathrm{CO}_{3}\end{array}$ & $\begin{array}{c}0.03 \mathrm{SiO}_{2}- \\
0.05 \mathrm{CaO}\end{array}$ & $\begin{array}{l}0.5-1.5 \mathrm{~h} \text { : cristobalite }+ \text { wollastonite }-2 M+ \\
\text { calcium oxide }+ \text { larnite } \\
2 \mathrm{~h}: \text { wollastonite }-2 M+\text { calcium oxide }+ \text { larnite }\end{array}$ \\
\hline 2 & $\begin{array}{l}\text { 3.000 g Tripoli }+1.000 \mathrm{~g} \mathrm{CaCO}_{3}+ \\
\quad 0.076 \mathrm{~g} \mathrm{Na}_{2} \mathrm{CO}_{3}\end{array}$ & $\begin{array}{c}0.03 \mathrm{SiO}_{2}- \\
0.01 \mathrm{CaO}\end{array}$ & $\begin{array}{l}0.5 \mathrm{~h}: \text { wollastonite }-2 M+\text { cristobalite }+ \text { calcium } \\
\text { oxide + Larnite } \\
1-2 \mathrm{~h}: \text { wollastonite }-2 M+\text { cristobalite }\end{array}$ \\
\hline 3 & $\begin{array}{l}3.000 \mathrm{~g}_{\text {Tripoli }}+2.000 \mathrm{~g} \mathrm{CaCO}_{3}+ \\
0.096 \mathrm{~g} \mathrm{Na}_{2} \mathrm{CO}_{3}\end{array}$ & $\begin{array}{l}0.03 \mathrm{SiO}_{2}- \\
0.03 \mathrm{CaO}\end{array}$ & $\begin{array}{l}0.5 \mathrm{~h} \text { : wollastonite- } 2 M+\text { cristobalite }+ \text { calcium } \\
\text { oxide + larnite } \\
1 \mathrm{~h}: \text { wollastonite- } 2 M+\text { calcium oxide }+ \\
\text { cristobalite } \\
1.5-2 \mathrm{~h} \text { : wollastonite- } 2 M\end{array}$ \\
\hline 4 & $3.000 \mathrm{~g}$ Tripoli $+2.000 \mathrm{~g} \mathrm{CaCO}_{3}$ & $\begin{array}{c}0.03 \mathrm{SiO}_{2}- \\
0.03 \mathrm{CaO}\end{array}$ & $\begin{array}{l}2 \mathrm{~h} \text { : wollastonite- } 2 M+\text { cristobalite }+ \text { calcium } \\
\text { oxide + larnite } \\
5 \text { h: wollastonite- } 2 M+\text { calcium oxide }+ \\
\text { cristobalite } \\
7-10 \text { h: wollastonite- } 2 M\end{array}$ \\
\hline
\end{tabular}

of quartz, 'meta-cristobolite' and calcium oxide is observed, thus resulting in only wollastonite- $2 M$.

As specified in the above paragraph, 'Tripoli rock' contains minor amounts of clay minerals. Pimraksa and Chindaprasirt (2009) studied the diatomaceous earth of the Lampand Province in the north of Thailand and observed that is constituted not only by diatoms, but also by clay minerals such as kaolinite, montmorillonite and illite. They used this diatomaceous earth for the production of lightweight bricks and analysed their pozzolanic behaviour. The authors observed that calcination temperature of $700^{\circ} \mathrm{C}$ led to dehydroxylation of kaolinite (Le Chatelier, 1887; Jeffries, 1944; Frost and Vassallo, 1996; Fernandez et al., 2011); it resulted in the collapse of the clay minerals structures as confirmed by the disappearance of clay minerals peaks in the XRD spectra, and relative change of the coordination state of $\mathrm{Si}$ and $\mathrm{Al}$ atoms as traced by NMR (Sanz et al., 1988; Chandrasekhar, 1996; Gimeno et al., 2003; Drits et al., 2016).

Also, in the present case, the calcination temperature of $1000^{\circ} \mathrm{C}$ causes the disruption of clay minerals structures and this is confirmed by the absence of the peaks characteristic of clay minerals in the XRD spectra of Figs 1,2 and 3, so we can state that the presence of clay minerals does not constitute an obstacle in the synthesis of wollastonite.

As far as the presence of 'meta-cristobolite' in the analysed spectra is concerned, Vakalova et al. (2009) report active crystallization of this phase during heating of an amorphous-crystalline raw material (diatomite) at $1000^{\circ} \mathrm{C}$; in particular, the authors explain that crystallization of 'meta-cristobolite' can be caused both by transformation of quartz and by crystallization of amorphous silica components. In fact, the 'Tripoli' raw mineralogical assemblage is characterized by the presence of minor quantities of crystalline quartz. When analysing the spectrum at $0.5 \mathrm{~h}$ (synthesis run 2) the presence of quartz is associated with that of 'meta-cristobolite'; in the successive spectrum registered at $1 \mathrm{~h}$, a reduction in the height of quartz peaks is evident and a contemporary increase in counts relative to cristobalite peaks is seen (magnified area in Fig. 2). The same considerations can be made for synthesis run 3 the with respect to the sample at 0.5 and $1 \mathrm{~h}$, respectively (magnified area in Fig. 3). In particular, no evidence of 'metacristobolite' is revealed in the spectrum at $0.5 \mathrm{~h}$ of synthesis run 3, thus proving that the rate of transformation of quartz in 'meta-cristobolite' is higher in synthesis run 3 than in synthesis run 2.

In run synthesis 1 no evidence of quartz is revealed, this signifying that disruption of this mineral in favour of 'meta-cristobolite' proceeds at a higher rate than in the other synthesis runs.

From the analysis of the above spectra, it is clear that all the synthesis runs show the crystallization of wollastonite- $2 M$.

In particular, synthesis runs 1 and 2 always provide the crystallization of wollastonite- $2 M$ in 


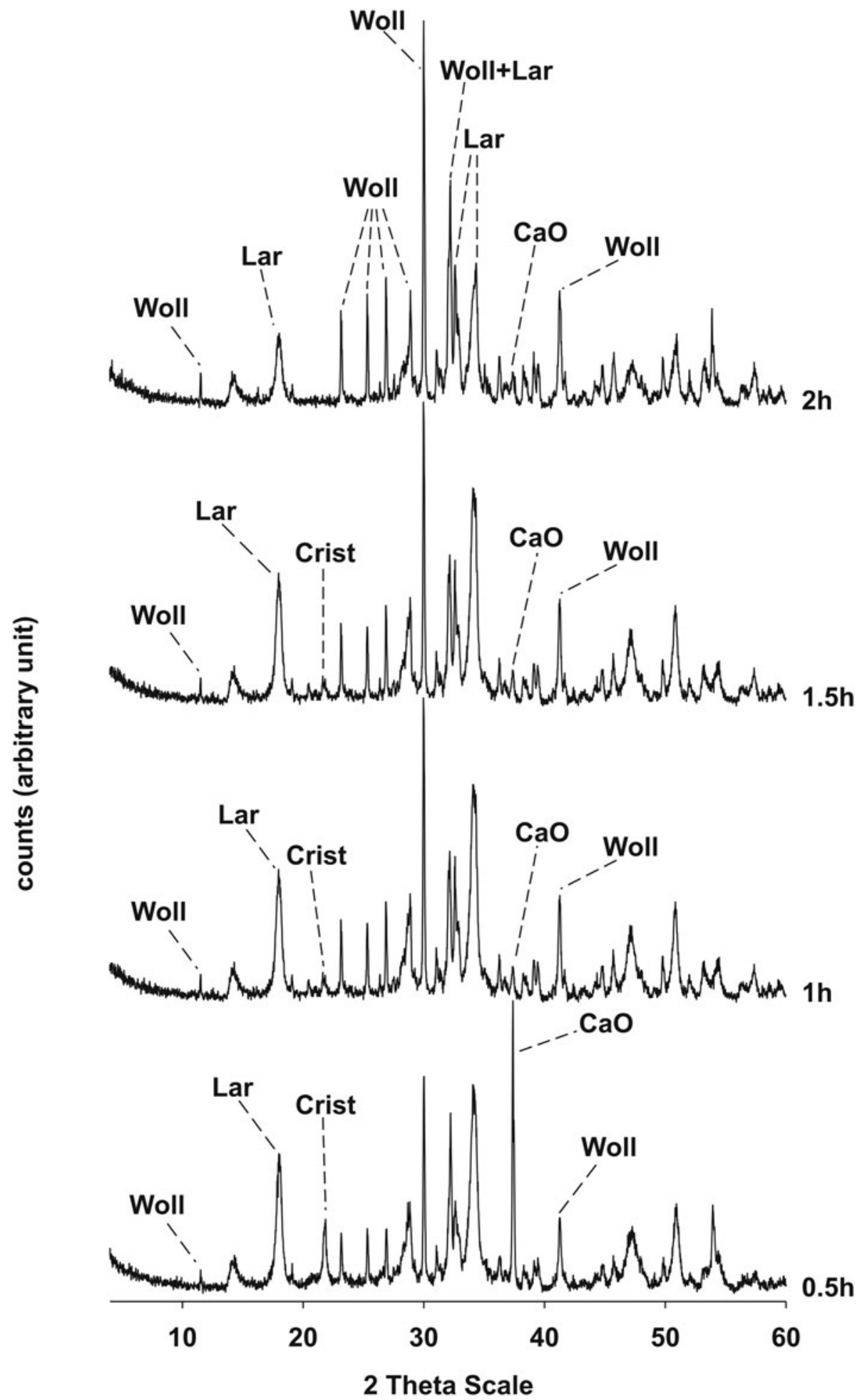

FIG. 1. PXRD analysis of synthesis run 1. Woll: wollastonite-2M; Lar: Larnite; Crist: cristobalite. 

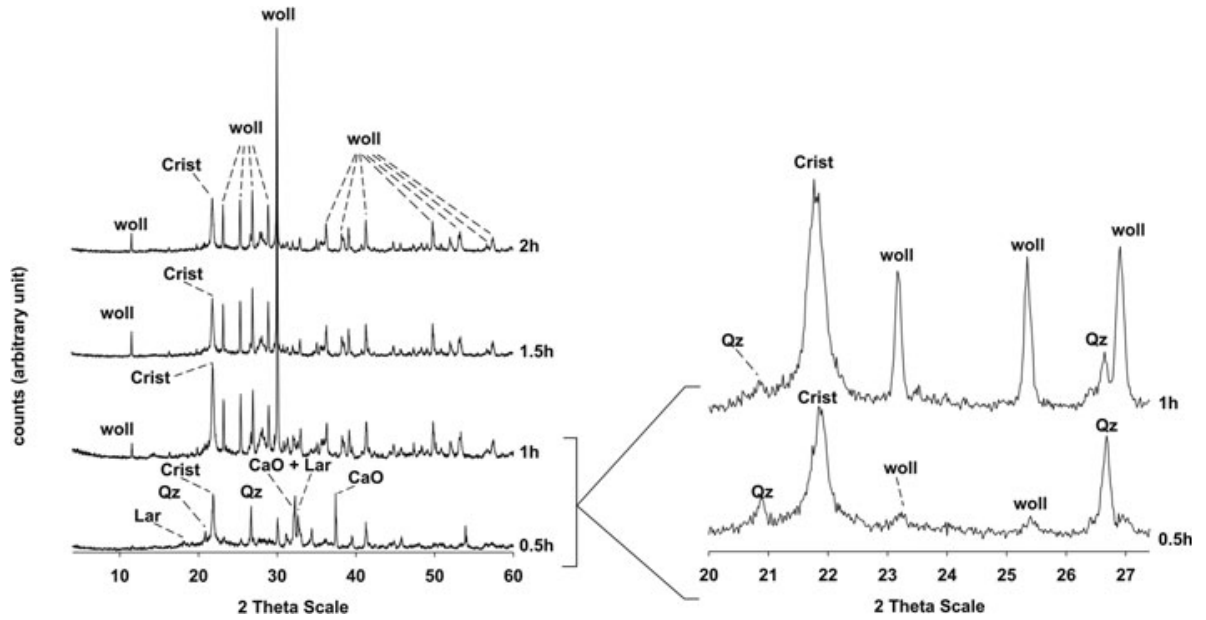

FIG. 2. PXRD analysis of synthesis run 2. Woll: wollastonite-2M; Lar: Larnite; Crist: cristobalite; Qz: quartz.

association with other phases. The presence of unreacted $\mathrm{CaO}$ is confirmed at the end of synthesis run 1 , attesting to the non-optimal kinetic condition achieved here; additionally the presence of the dicalcic-silicate larnite is also proven at the end of the run, thus proving a starting mixture characterized by an excess in $\mathrm{CaO}$ with respect to the stoichiometry of the wollastonite formula.
However, at the end of synthesis run 2 unreacted $\mathrm{CaO}$ was not revealed to be present; it can also be stated that in this case larnite appears as a metastable phase during the transient, fastdisappearing sample at $1 \mathrm{~h}$. On the contrary, 'meta-cristobolite' remains at the end of the run in association with wollastonite- $2 M$, and this is due to the starting mixture having an excess of $\mathrm{SiO}_{2}$

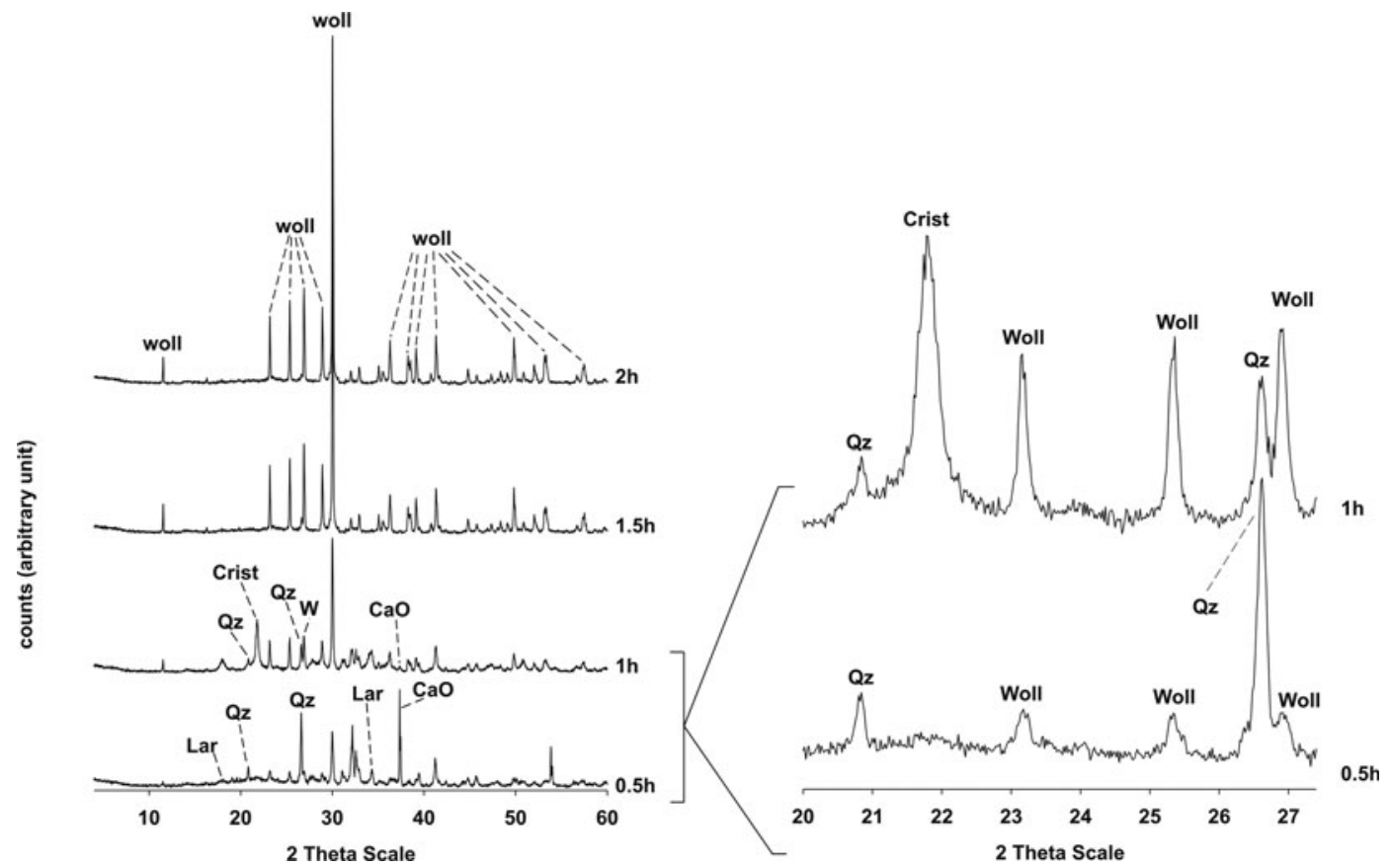

FIG. 3. PXRD analysis of synthesis run 3. Woll: wollastonite-2M; Lar: Larnite; Crist: cristobalite; Qz: quartz. 
with respect to the stoichiometry of the wollastonite formula.

Run synthesis 3 appears to be the most ideal, as wollastonite is the only phase present in the time interval $1.5-2 \mathrm{~h}$.

Once established that the best conditions in the synthesis of wollastonite- $2 M$ are those of synthesis run 3, a fourth experiment (synthesis run 4) was performed without the use of $\mathrm{Na}_{2} \mathrm{CO}_{3}$, in order to test the real utility of the mineralizer (Table 1). The results of the XRD analyses are reported in Fig. 4.

The results show a slowdown in the kinetics of synthesis: wollastonite- $2 M$ is in fact associated with calcium oxide, larnite and quartz at $2 \mathrm{~h}$; appearance of 'meta-cristobolite' is observed at $5 \mathrm{~h}$; and in the time interval $7-10 \mathrm{~h}$ quartz, 'meta-cristobolite' and calcium oxide disappear, thus resulting in pure wollastonite- $2 M$. These results are quite coherent with the ones obtained, at lesser temperatures and much larger times in the classical work of Harker and Tuttle (1956).

The results of synthesis run 4 confirmed the efficacy of the use of $\mathrm{Na}_{2} \mathrm{CO}_{3}$ as a triggering agent. For these reasons, only synthesis run 3 was considered for more detailed characterizations.

Rietveld structural refinement was conducted on synthesis run 3. In Fig. 5 the observed and calculated profiles and difference plot for

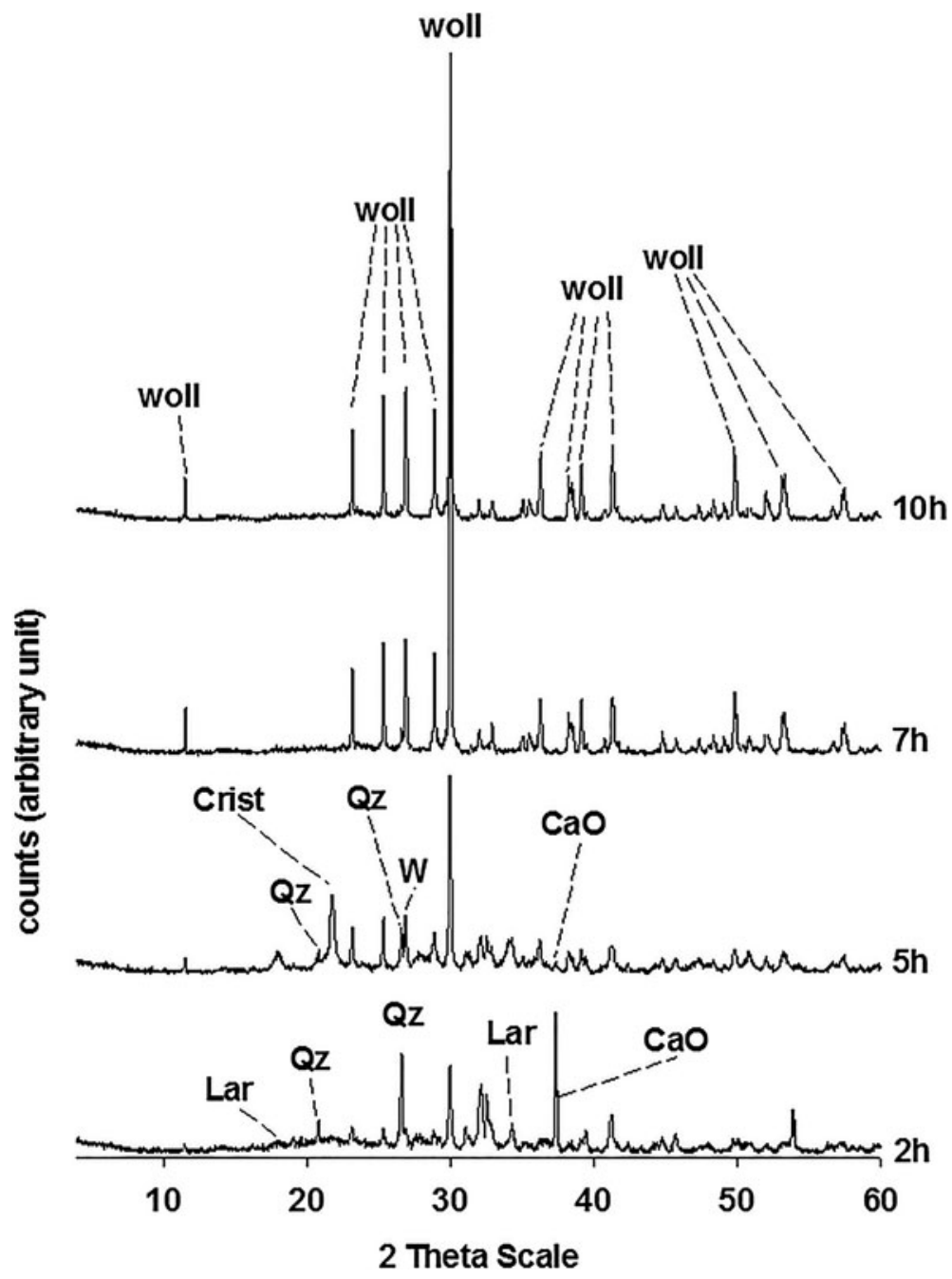

FIG. 4. PXRD analysis of synthesis run 4. Woll: wollastonite-2M; Lar: Larnite; Crist: cristobalite; Qz: quartz. 


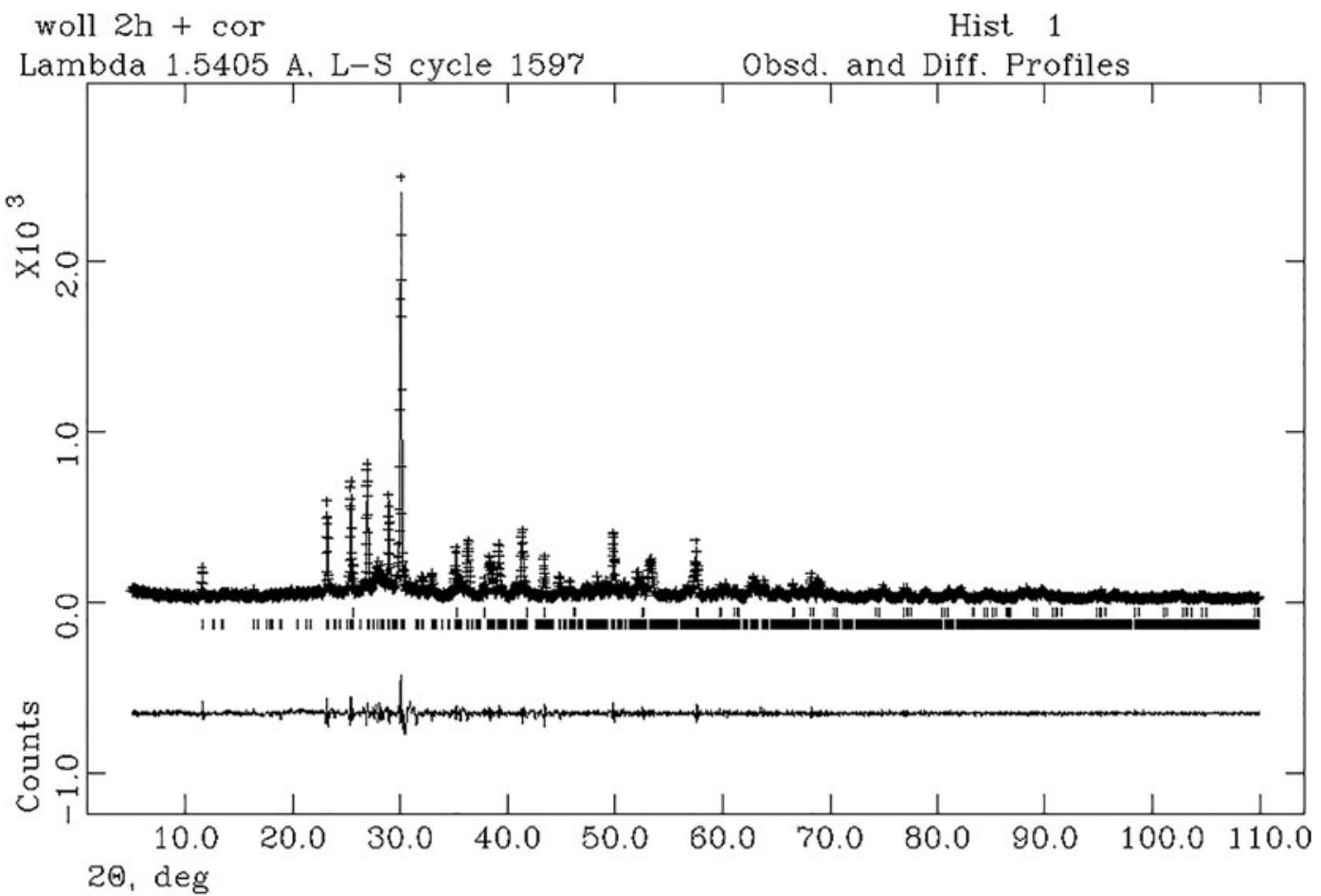

Fig. 5. Rietveld refinement plots: Observed (+) and calculated profiles and difference plot for wollastonite- $2 M$ and corundum NIST 676a with tick marks at the positions of the Bragg peaks. From the bottom: wollastonite-2M, corundum NIST 676a.

wollastonite- $2 M$ and corundum NIST $676 \mathrm{a}$ with tick marks at the positions of the Bragg peaks are reported for the sample at $2 \mathrm{~h}$ of synthesis run 3. Results of the Rietveld refinement are shown in

TABLE 2. Experimental conditions and crystallographic data for Rietveld refinement.

\begin{tabular}{lc}
\hline Sample & $\begin{array}{c}2 \mathrm{~h} \text {, synthesis run } 3+10 \% \\
\text { corundum NIST } 676 \mathrm{a}\end{array}$ \\
\hline Wavelength $(\AA)$ & 1.5418 \\
No. of observation & 1597 \\
$R_{\mathrm{wp}}$ & 0.16 \\
$R_{\mathrm{p}}$ & 0.12 \\
$\mathrm{CHI}^{2}$ & 2.35 \\
Space group & $P 2_{1} / a$ \\
wollastonite-2M & \\
$a(\AA)$ & $15.42264(54)$ \\
$b(\AA)$ & $7.31691(61)$ \\
$c(\AA)$ & $7.05752(49)$ \\
$\%$ amorphous & $3.5(9)$ \\
$\%$ wollastonite-2M & $96.3(9)$ \\
\end{tabular}

Table 2. The cell parameters, refined with a monoclinic symmetry, space group $P 2_{1} / a$, are $a_{0}$ $=15.42264(54) ; \quad b_{0}=7.31691(61) \AA$ and $c_{0}=$ 7.05752(49) $\AA$. The results of the QPA (Table 2) indicate that the calculated amorphous phase in the sample at $2 \mathrm{~h}$ of synthesis run 3 is $3.5(9) \%$, thus resulting in a final product of $96.3(9) \%$ wollastonite- $2 M$.

Chemical analysis of wollastonite- $2 M$ (sample at $2 \mathrm{~h}$ of synthesis run 3 ) is reported in Table 3 . The values of the $\mathrm{SiO}_{2} / \mathrm{CaO}$ ratio are in agreement with bibliographic data (Tolliday, 1959). The chemical formula of wollastonite- $2 M$ was calculated to $\left(\mathrm{Si}_{5.91} \mathrm{Al}_{0.11}\right)\left(\mathrm{Ca}_{5.93} \mathrm{Mg}_{0.07} \mathrm{~K}_{0.04}\right) \mathrm{O}_{18}$.

\section{Morphological and physical characterization}

The textural characterization of synthesis run 3 is illustrated in Fig. $6 a-b$. Clear crystals of 'parawollastonite' are visible in the sample at $2 \mathrm{~h}$. They have an acicular-needle shaped morphology; the average size of the crystals is of $\sim 7 \mu \mathrm{m}$ long and $\sim 0.9 \mu \mathrm{m}$ wide. 
TABLE 3. Chemical analysis of the sample at $2 \mathrm{~h}$, synthesis run 3.

\begin{tabular}{lcccccccc}
\hline Sample & $\mathrm{CaO}[\%]$ & $\mathrm{SiO}_{2}[\%]$ & $\mathrm{Al}_{2} \mathrm{O}_{3}[\%]$ & $\mathrm{MgO}[\%]$ & $\mathrm{K}_{2} \mathrm{O}[\%]$ & $\mathrm{SiO}_{2} / \mathrm{CaO}$ & Time (h) & XRD spectrum \\
\hline $\mathrm{ICP}-2 \mathrm{~h}$ & 47.5 & 50.75 & 0.11 & 0.07 & 0.04 & 1.06 & $2 \mathrm{~h}$ & Wollastonite-2M \\
Woll-2M $\left(^{\mathrm{a}}\right)$ & 47.73 & 51.56 & 0.15 & 0.26 & 0 & 1.08 & - & - \\
\hline
\end{tabular}

(a) data after Tolliday (1959).

The specific surface of the mineral (Table 4) is $1.4203(35) \mathrm{m}^{2} / \mathrm{g}$, in good agreement with the range interval reported by Teir et al. (2005). A density of $2.79(3) \mathrm{g} / \mathrm{cm}^{3}$ was calculated for wollastonite- $2 M$; this value is comparable to that proposed by Grigoryan et al. (2008) for the same mineral.

\section{Infrared spectroscopy and ${ }^{29}$ Si magic angle spinning nuclear magnetic resonance}

Infrared spectroscopy (IR) absorption spectra obtained from synthesis run 3 (samples at 1.5 and $2 \mathrm{~h}$ ) are shown in Fig. 7. Values of absorption bands found here are compiled in Table 5 together with known data for 'parawollastonite' (Ptacek et al., 2010). In particular, six bands are present in the region of the asymmetric stretch and located, respectively, at 1086, 1063, 1012, 962, 936 and $898 \mathrm{~cm}^{-1}$. On the other hand, a sole band is related to the symmetric stretching band and positioned at $683 \mathrm{~cm}^{-1}$.

The ${ }^{29} \mathrm{Si}$ MAS-NMR spectrum of wollastonite$2 M$ (sample at $2 \mathrm{~h}$, synthesis run 3 ) is illustrated in Fig. 8; it reveals a peak at $-92.95 \mathrm{ppm}$ attributed to the $\mathrm{Si}(4 \mathrm{Al})$ site in the mineral structure, a position coherent with data by Gillespie (2007).

\section{Geological consequences}

The occurrence of wollastonite in plutonic, i.e. (granitic)-carbonatic host-rock contacts is a relatively common and limited (in most cases some $\mathrm{cm}$ thick) effect of metasomatism of silica. In these cases evidence of widespread assimilation of limestone by magma seems to be rare, and it is difficult to note these effects on the magmatic side of the contact. In contrast, in volcanic or shallow (basaltic) subvolcanic environments a number of cases (Reverdatto, 1970, Nichols, 1971, Sabine and Young, 1975, Baker and Black, 1980, Michaud, 1995, Chadwick et al., 2007) of pyrometamorphism of limestone (and flint) xenoliths have been described, along with limited, but very characteristic, assimilation of lime by magma (increase of total lime of $30-60 \%$ ); available data suggest that the range of temperature might be $1000-1100^{\circ} \mathrm{C}$ or higher. Under these circumstances, wollastonite is a common phase in the paragenesis, both on the metamorphic rock and as phenocrysts and microliths in the volcanic rock

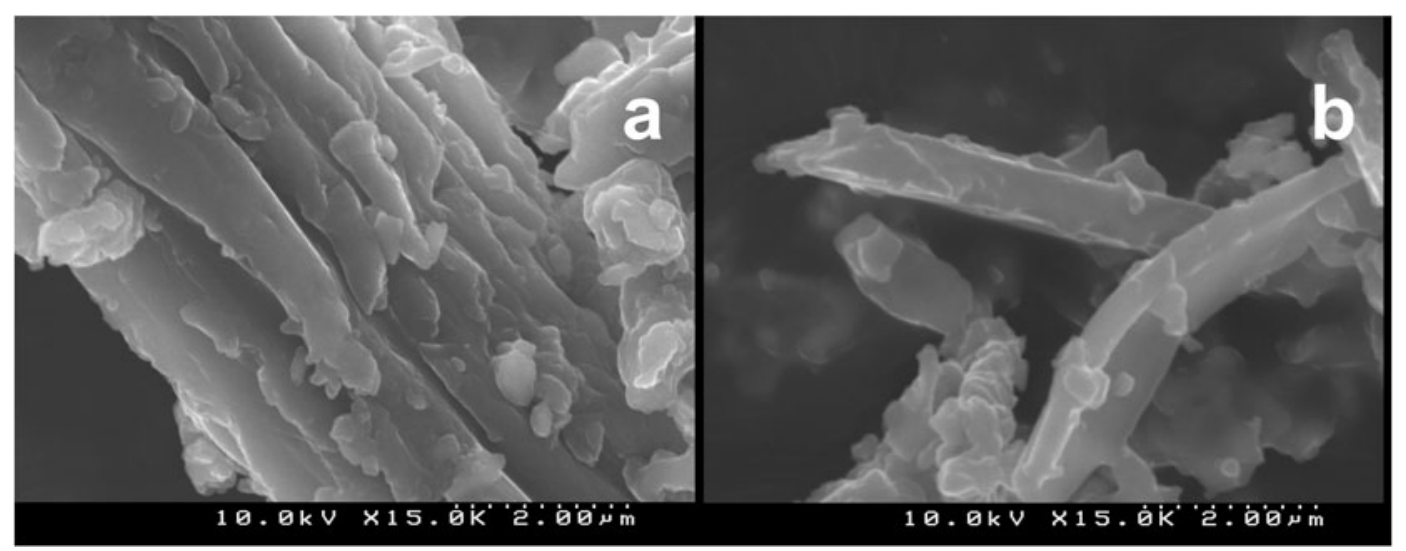

FIG. $6 a-b$ : SEM images of wollastonite- $2 M$ crystals synthesized at $2 \mathrm{~h}$ (run synthesis 3 ). 
TABLE 4. Calculated specific surface and density for wollastonite- $2 M$ (sample at $2 \mathrm{~h}$, synthesis run 3 ) compared to available data.

\begin{tabular}{lcc}
\hline Sample & Density & Specific surface \\
\hline Woll 2 h & $2.79(3) \mathrm{g} / \mathrm{cm}^{3}$ & $1.4203 \pm 0.0035 \mathrm{~m}^{2} / \mathrm{g}$ \\
Wollastonite- & $2.7382 \mathrm{~g} / \mathrm{cm}^{3}\left(^{\mathrm{a}}\right)$ & $0.8-4 \mathrm{~m}^{2} / \mathrm{g}\left({ }^{\mathrm{b}}\right)$ \\
$2 M$ & & \\
& & \\
\hline
\end{tabular}

(a) after Grigoryan et al. (2008)

(b) after Teir et al. (2005)

(see Sabine and Young, 1975, Baker and Black, 1980). Precipitation of wollastonite forming liquid has been also described in Ca-rich synthetic medieval glass (see Gimeno and Pugès, 2002) and industrial glass (Pirsson, 1910). Also, late-stage hydrothermal metasomatic generation of wollastonite (i.e. hydrogrossular) is not uncommon, together with the occurrence of other minerals in the range of $850-650^{\circ} \mathrm{C}$ or less (Sabine and Young, 1975, Baker and Black, 1980).

In most of these occurrences the calc-silicate paragenesis is complex, and therefore it is somewhat difficult to interpret directly in terms of temperature of formation (under low-pressure conditions). Also, some of the characteristic mineral phases of basaltic magma (typically clinopyroxene) continue to change their composition, with a sharp increase of lime in the final stoichiometry of the resulting phase. Thus the approach required to study the types of mineral reactions involved, the phases present (stable and metastable) in the paragenesis, the kinetics of the crystallization process, the telescoping of paragenesis under successive retrograding conditions, the trace-element balance of the assimilation process, and even the true significance and dimension of these assimilations remains

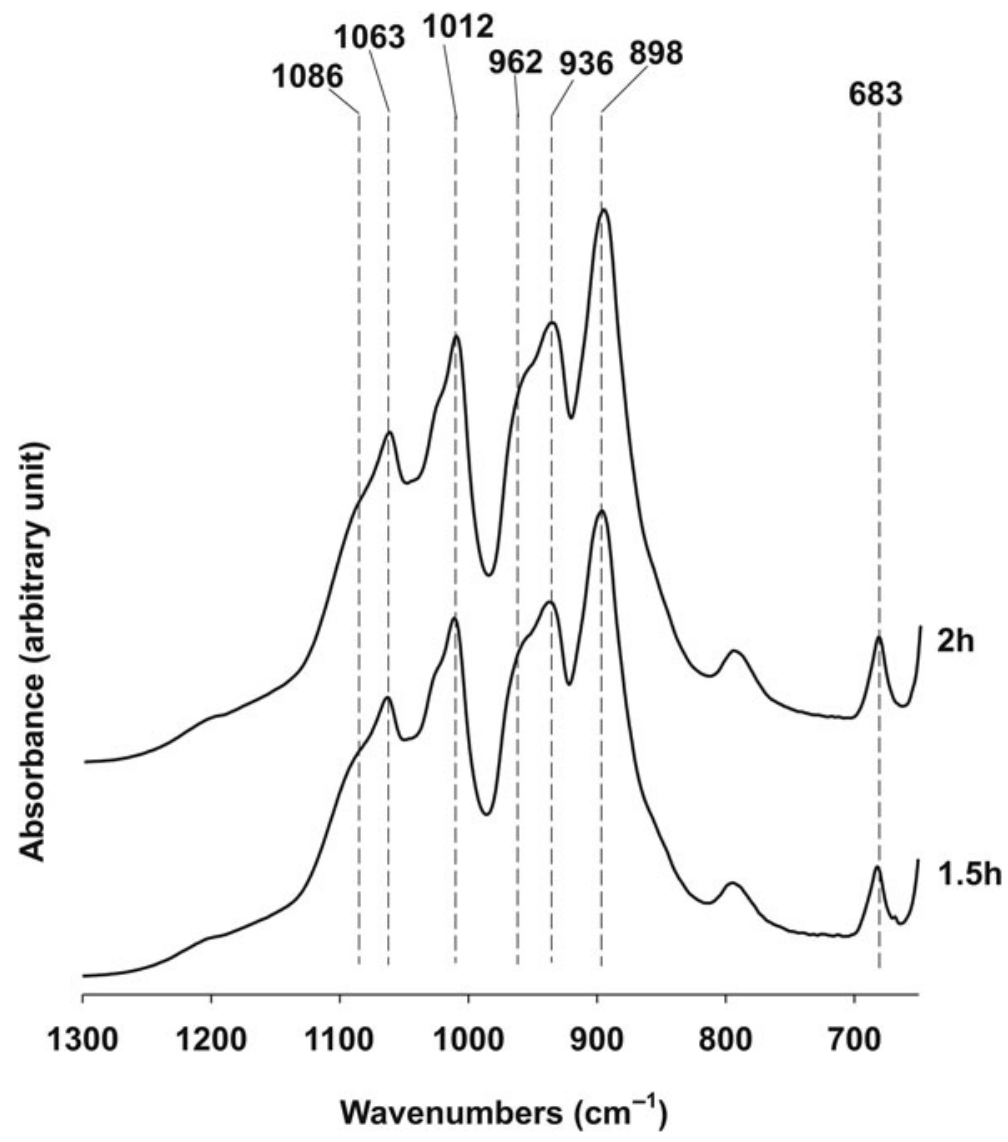

FIG. 7. Infrared spectra of synthesis run (3). 
TABLE 5. Infrared adsorption bands for wollastonite$2 M$, run synthesis (3).

\begin{tabular}{lcc}
\hline Sample & $\begin{array}{c}\text { Asymmetric stretch } \\
\text { Si-O-Ca }\end{array}$ & $\begin{array}{c}\text { Symmetric } \\
\text { stretch } \\
\text { Si-O-Si }\end{array}$ \\
\hline 2 h & $1086,1063,1012,962,936,898$ & 683 \\
Woll ( $\left.{ }^{(}\right)$ & $1081,1060,1016,965,925,900$ & 682 \\
\hline
\end{tabular}

${ }^{\left({ }^{a}\right)}$ after Ptacek et al. (2010).

obscure. A possible way to increase our knowledge is to continue the work developed here, with the design of specific experiments for the main single phases involved (i.e. diopside, grossular, etc.) in order to clarify the range of temperature and the minimum time required in order to achieve the synthesis of each phase.

A very interesting (and still poorly developed) method for investigating pyrometamorphism and carbonate assimilation processes is the study of radiogenic isotopic mineral chemistry, a fact that has been explored by studying the intracrystalline isotope variation in plagioclase phenocrysts in the case of the Merapi volcano, Java, Indonesia (Chadwick et al., 2007), the whole rock (and groundwater) strontium exchange in a subvolcanic plug (Sabine et al., 1982), and, in a pyroclastic context, by the separate study of the mineral radiogenic isotope $(\mathrm{Sr})$ chemistry (diopside, salite, feldspar, glass and whole rock) during the evolution of a single eruptive (Mercato) event of Vesuvius (Aulinas et al., 2008).

\section{Conclusions}

This work has achieved the synthesis of wollastonite- $2 M$ from a natural, cheap, and abundant geological resource by a simple chemical process. Among the three synthesis runs proposed, the best results are demonstrated for synthesis run 3; in fact in this case, the presence of 'parawollastonite' is shown as isolated after only $1.5 \mathrm{~h}$ of thermal treatment. When replicating this experiment in the absence of the mineralizer a remarkable dilation of synthesis rates is shown as the presence of sole wollastonite is reached with $5.5 \mathrm{~h}$ of delay. The use of diatomite as a reactant suggests that the synthesis might be enhanced, or at least can produce intermediate products not usually considered in previous investigations.

The efficacy of the experimental protocol proposed here is tested through chemical-physical, crystallographic, morphological and spectroscopic characterization of experimental products of synthesis run 3.

The results give values comparable to those reported in the literature for the mineral. Estimation of the amorphous phase in the synthesis powders gives a final product of $96.3 \%$ wollastonite- $2 M$.

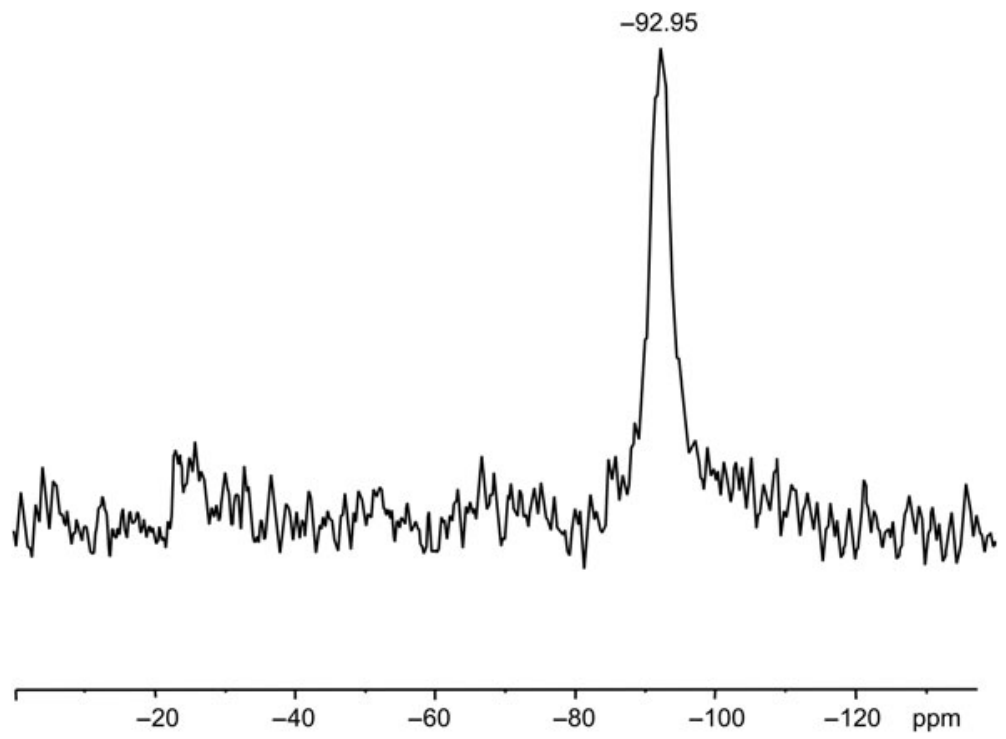

FIG. $8{ }^{29}$ Si MAS-NMR spectrum: sample at $2 \mathrm{~h}$ (synthesis run 3 ) of wollastonite-2M. 
These results seem to allow transfer to an industrial production scale.

This experimental work can also be applied to the geological problem of pyrometamorphism (sanidinite-facies conditions) of limestone xenoliths by basic magmas in shallow or earth-surface environments. The results suggest that synthesis can be easily achieved in extremely short periods of time (hours) and therefore can be produced during an ongoing eruption, both in thick, quickly deposited, proximal piles of agglomerate (made by bombs with a xenolithic limestone core), in xenolithic limestone-bearing lava flows or in a shallow intrusive environment at the top of a magmatic chamber where the host rocks are constituted by limestone (i.e. Vesuvius). In earthsurface or in a shallow open-system media $\mathrm{CO}_{2}$ can be evacuated and this greatly favours the formation of wollastonite, in contrast to closedsystem regional or contact metamorphism.

In addition, this investigation offers new questions to be explored in the future: how comparable is the experimental work conducted with a magmalimestone interaction? How comparable are basic and silicic magmas with respect to wollastonite synthesis (influence of composition, lower temperature in the case of the silicic one, kinetics of the reaction)? It also seems to be necessary to introduce $\mathrm{MnO}$ (and $\mathrm{FeO}$ ) into the reagents in order to reach the best reproduction of natural wollastonite.

On other hand, this study does not clarify the lesser viable temperature conditions for wollastonite synthesis, a fact of twofold interest: industrial and in terms of metamorphic petrology (i.e. does wollastonite develop as an exhalite sediment under high-temperature hydrothermal conditions?).

Last but not least, the use of amorphous silica (diatomite) in the synthesis confirms that 'metacristobolite' is synthesized and this shows that the well-established $\mathrm{SiO}_{2}-\mathrm{CaO}-\mathrm{CO}_{2}$ system merits further experimental attention in the low-temperature field.

\section{Acknowledgements}

The analytical work was supported by the CGL201128022 of MICINN Spanish research contract (responsible D.G.). The chemical treatment of raw material, synthesis processes and XRD characterization of synthesized zeolites were performed at the Dipartimento di Ingegneria e Geologia dell'Università "D'Annunzio", Chieti, Italy. All the other analyses were conducted at the Centres Científics i Tecnològics of the Universitat de Barcelona (CCiT-UB), Spain. The authors thank the technical staff at CCiT (UB) for their help during the work.

\section{References}

Aulinas, M., Civetta, L., Di Vito, M., Orsi, G., Gimeno, D., and Fernandez-Turiel, J.L. (2008) The Plinian Mercato eruption of Somma Vesuvius: Magma chamber processes and eruption dynamics. Bulletin of Volcanology, 70, 825-840.

Baker, C.K. and Black, P.A. (1980) Assimilation and metamorphism at a basalt-limestone contact, Tokatoka, New Zealand. Mineralogical Magazine, 43, 797-807.

Beisswenger, A. (1996) The origin of the Canton SaintOnge wollastonite deposit, Lac-Saint-Jean, Québec. Unpublished MsSc Thesis, Université du Québec à Chicoutimi, Canada, 143 pp.

Brown, T.J., Bide, T., Walters, A.S., Idoine, N.E., Shaw, R. A., Hannis, S.D., Lusty, P.A.J. and Kendall, R. (2011) World Mineral Production 2005-09. British Geological Survey, Keyworth, Nottingham, UK, 109 pp.

Bryden, R., Konsztowicz, K.J., Caley, W.F. and Kingston, P.W. (1992) Co-dispersion of mullite and wollastonite in aqueous suspensions. Ceramic Engineering \& Science Proceedings, 13(9-10), 1058-1065.

Chadwick, J.P., Troll, V.R., Ginibre, C., Morgan, D., Gertisser, R., Waight, T.E. and Davidson, J.D. (2007) Carbonate assimilation at Merapi Volcano, Java, Indonesia: Insights from crystal isotope stratigraphy. Journal of Petrology, 48(9), 1793-1812.

Chandrasekhar, S. (1996) Influence of metakaolinization temperature on the formation of zeolite $4 \mathrm{~A}$ from kaolin. Clay Minerals, 31, 253-261.

Dawson, J.B., Smith, J.V. and Steele, J.M. (1992) 1966 ash eruption of the carbonatite volcano Oldoinyo Lengai: mineralogy of lapilli and mixing of silicate and carbonate magmas. Mineralogical Magazine, 56, 1-16.

Deer, W.A., Howie, R.A. and Zussman, J. (1978) RockForming Minerals. Volume $2 A$ Single-Chain Silicates. Edition Longman Group London, 668 pp. ISBN 9780-85272-678-5.

Demidenko, N.I. and Konkina, E.S. (2003) Sintering of ceramic mixtures based on natural wollastonite. Steklo i Keramika, 1, 15-16.

Drits, V.A., Derkowski, A., Sakharov, B.A. and Zviagina, B.B. (2016) Experimental evidence of the formation of intermediate phases during transition of kaolinite into metakaolinite, American Mineralogist, 101, 2331-2346.

Fernandez, R., Martirena, F. and Scrivener, K.L. (2011) The origin of the pozzolanic activity of calcined clay minerals: A comparison between kaolinite, illite and montmorillonite. Cement and Concrete Research, 41, $113-122$. 
Fernandez-Turiel, J.L., Gimeno, D., Valero, F., Carnicero, M. and Rodríguez, J.J. (2003) Spatial and seasonal water quality in a mediterranean catchment: the Llobregat river (NE Spain). Environmental Geochemistry and Health, 25, 253-474.

Frost, L. and Vassallo, A.M. (1996). The dexydroxylation of the kaolinite clay minerals using infrared emission spectroscopy ray. Clays and Clay Minerals, 44, 635-651.

Gillespie, P.A. (2007) Silicon Complexes in Silicon Doped Calcium Phosphate Biomaterials. Unpublished BSc Thesis, Queen's University Kingston, Ontario, Canada.

Gimeno, D. and Pugès, M. (2002) Caracterización química de la vidriera histórica de Sant Pere i Sant Jaume (Monestir de Pedralbes, Barcelona). Boletín de la Sociedad Española de la Cerámica y el Vidrio, 41, 13-20.

Gimeno, D., Davidovits, J., Marini, C., Rocher, P., Tocco, S., Cara, S., Diaz, N., Segura, C. and Sistu, G. (2003): Desarrollo de un cemento de base silicatada a partir de rocas volcánicas vitreas alcalinas: interpretación de los resultados preindustriales basada en la composición químico-mineralógica de los precursores geológicos. Boletín de la Sociedad Española de la Cerámica y el Vidrio, 42, 69-78.

Gladun, V.D., Khol'kin, A.I. and Akat'eva, L.V. (2007) Prospects for production of synthetic wollastonite in Russia. Inorganic Technology, 41, 606-609.

Glasser, F.P. and Taylor, H.F.W. (1978) Quimica de los tratamientos hidrotermicos y de las soluciones acuosas, analisis termogravimetrico y determinacion de humedad. Pp. 357-380 in: 25 de "La Quimica de los Cementos" (Por H.F.W. Taylor, editor). Vol. II. Urmo, Bilbao.

Grigoryan, K.G., Arutyunyan, G.A. and Grigoryan, G. (2006) Wollastonite from hydrothermal synthesized calcium hydrometasilicate obtained from modifications of silica. Journal of American Ceramics Society, 89, 374-376.

Grigoryan, K.G., Arutyunyan, G.A., Baginova, L.G. and Grigoryan, G.O. (2008) Synthesis of calcium hydromonosilicate from diatomite under hydrothermal conditions and its transformation into wollastonite. Technology of Inorganic Substances and Materials, 42, 583-585.

Grigoryan, G. O., Arutyunyan, G.A., Grigoryan, K.G. and Khachatryan, A.A. (2010) Synthesis of wollastonite from the carbonate-containing gaize of Lithuania. Inorganic Tecnology, 44, 476-478.

Gualtieri, A.F. (2000) Accuracy of XRPD QPA using the combined Rietveld-RIR method. Journal of Applied Crystallography, 33, 267-278.

Harker, R.I. and Tuttle, O.F. (1956) Experimental data on the $\mathrm{P}_{\mathrm{CO} 2}-\mathrm{T}$ curve for the reaction: calcite + quartz $=$ wollastonite + carbon dioxide. American Journal of Science, 254, 239-256.
Hench, L.L. (1991) Bioceramic from concept to clinic. Journal of the American and Ceramic Society, 74, 1487-1510.

Hesse, K.F. (1984) Refinement of the crystal structure of wollastonite-2M (parawollastonite). Zeitschrift für Kristallographie, 168, 93-98.

Ibañez, A. and Sandoval, F. (1993) La wollastonite: proprietades, sintesis y aplicaciones ceramicas. Boletín de la Sociedad Española de la Cerámica y el Vidrio, 32, 349-361.

Ibañez, A., Pena, J. MC. and Sandoval, F. (1990) Solid state reaction for producing $\beta$-wollastonite. Ceramic Bullettin, 69, 374-378.

Jeffries, C.D. (1944) Quantitative approach to the study of thermal characteristics of clays. Soil Science Society of America Proceedings, 9, 86-91.

Justness, H. (2012) Alternative low-CO2 "green" clinkering processes. Pp. 83-89 in: Applied Mineralogy of Cement \& Concrete (M.A.T.M. Broekmans and H. Pöllmann, editors). Reviews in Mineralogy \& Geochemistry, 74. Chantilly, Virginia, USA.

Kotsis, I. and Balogh, A. (1989) Synthesis of wollastonite. Ceramics International, 15, 79-85.

Kridelbaugh, S.J. (1973) The kinetics of the reaction calcite + quartz $=$ wollastonite + carbon dioxide at elevated temperatures and pressures. American Journal of Science, 273, 757-777.

Kurczyk, H.G. (1977) Synthetic diopside and synthetic wollastonite- new raw materials for ceramics. Pp. 22-29 in: Proceedings of the 3rd International Meeting on Modern Ceramics Technologies. Advances in Ceramics Processing. Rimini, Italy.

Kurczyk, H.G. and Wuhrer, J. (1971) Synthetic wollastonite and its use in ceramic bodies. Interceram, 2, 119-125.

Lacroix, A. (1893) Les Enclaves des Roches Volcaniques. Annales de 1'Academie de Mâcon, t X. Protat Frères Imprimeurs, Mâcon.

Larson, A.C. and Von Dreele, R.B. (2004) General Structure Analysis System (GSAS). Los Alamos National Laboratory Report LAUR 86-748.

Le Chatelier, H. (1887) The action of heat on clays. Bullettin de la Société Géologique de France, 10, 204-211.

Lin, K., Chang, J. and Lu, J. (2006) Synthesis of wollastonite nanowires via hydrothermal microemulsion method. Materials Letters, 60, 30073010 .

MacKinnon, A. (1990) Wollastonite in Southeastern Ontario. Open File Report 5715, Ontario Geological Survey, Queen's Printer for Ontario, Canada, $289 \mathrm{pp}$.

Michaud, V. (1995) Crustal xenoliths in recent hawaiites from Mount Etna, Italy: evidence for alkali exchanges during magma-wall rock interaction. Chemical Geology, 122, $21-42$. 
Nichols, I.A. (1971) Calcareous inclusions in lavas and agglomerates of Santorini volcano. Contributions to Mineralogy and Petrology, 30, 261-276.

Nikonova, N.S., Tikhomirova, I.N., Belyakov, A.V. and Zakharov, A.I. (2003) Wollastonite in silicate matrices. Glass and Ceramics, 60, 342-346.

Nour, W.M.N., Mostafa, A.A. and Ibrahim, D.M. (2008) Recycled wastes as precursor for synthesizing wollastonite. Ceramics International, 34, 101-105.

Novembre, D., Di Sabatino, B., Gimeno, D., Garcia Valles, M. and Martinez-Manent, S. (2004) Synthesis of Na-X zeolites from tripolaceous deposits (Crotone, Italy) and volcanic zeolitized rocks (Vico Volcano, Italy). Microporous and Mesoporous Materials, 75, 1-11.

Novembre, D., Gimeno, D., Pasculli, A. and Di Sabatino, B. (2010a) Synthesis and characterization of sodalite using natural kaolinite: an analytical and mathematical approach to simulate the loss in weight of chlorine during the synthesis process. Fresenius Enviromental Bulletin, 19, 1109-1117.

Novembre, D., Pasculli, A., Pace, C., Gimeno, D. and Di Sabatino, B. (2010b) Synthesis of sodalite from natural kaolinite: A way to simulate the loss in weight of chlorine during the synthesis process by an analytical and mathematical modeling. Rendiconti Online Società Geologica Italiana, 11, 548-549.

Novembre, D., Di Sabatino, B., Gimeno, D. and Pace, C. (2011) Synthesis and characterization of Na-X, Na-A, Hydroxisodalite and Na-P zeolites from metakaolinite. Clay Minerals, 46, 336-354.

Novembre, D., Pace, C. and Gimeno, D. (2014) Synthesis and characterization of zeolites K-F and W type using a diatomite precursor. Mineralogical Magazine, 78, 1209-1225.

Pasculli, A. and Novembre, D. (2012) A phenomenological-mathematical approach in simulating the loss in weight of chlorine during sodalite synthesis. Computers and Geosciences, 42, 110-117.

Pavlov, V.F., Shefer, A.A. and Shabanov, V.F. (2008) Specific features of the crystallization of wollastonite. Glass Physics and Chemistry, 34, 470-473.

Philip, A. and Binet, M. (1971) Caractéristiques et utilisations céramiques d'un silicate monocalcique de synthèse. Industrial Céramics, 640, 401-404.

Pimraksa, K. and Chindaprasirt, P. (2009) Lightweight bricks made of diatomaceous earth, lime and gypsum. Ceramics International, 35, 471-478.

Pirsson, L.V. (1910) On an artificial lava flow and its spherulitic crystallization. American Journal of Science, Fourth Series, 30(176), 91-114.

Ptacek, P., Noskova, M., Brandstcetr, J., Soukal, F. and Opravil, T. (2010) Dissolving behavior and calcium release from fibrous wollastonite in acetic acid solution. Thermochimica Acta, 498, 54-60.
Rankin, G.A. and Wright, F.E. (1915) The ternary system $\mathrm{CaO}-\mathrm{Al}_{2} \mathrm{O}_{3}-\mathrm{SiO}_{2}$. American Journal of Science, $4^{\text {th }}$ series, 39(229), 1-79.

Reverdatto, V.V. (1970) Pyrometamorphism of limestones and the temperature of basaltic magmas. Lithos, $\mathbf{3}$, 135-143.

Rosa, D.F. (2004) Marble enclaves in the melt sheet at the West Clearwater Lake impact crater, Northern Quebec. Unpublished MsSc. Thesis, McGill University, Montréal, Québec, Canada, 146 pp.

Ruggieri, F., Fernandez-Turiel, J.L., Gimeno, D., Valero, F., Garcia, J.C. and Medina, M.E. (2008) Limestone selection criteria for EDr water remineralization. Desalination, 227, 314-326.

Ruggieri, F., Fernandez-Turiel, J.L., Saavedra, J., Gimeno, D. and Garcia-Valles, M. (2010) Environmental geochemistry of ancient volcanic ashes. Journal of Hazardous Materials, 183, 353-365.

Ruggieri, F., Fernandez-Turiel, J.L., Saavedra, J., Polanco, E. and Naranjo, J.A. (2011) Environmental geochemistry of recent volcanic ashes from Southern Andes. Environmental Chemistry, 8, 236-247.

Sabine, P.A. and Young, B.R. (1975) Metamorphic processes at high temperature and low pressure: the petrogenesis of the metasomatized and assimilated rocks of Carneal, Co. Antrim. Philosophical Transactions of the Royal Society of London. Series A, Mathematical and Physical Sciences, 280(1294), 225-269.

Sabine, P.A, Beckinsale, R.D., Evans, J.A. and Walsh, J. N. (1982) Geochemical and strontium-isotope studies of reactions between basic magma, chalk and flint, and the role of groundwater in the Carneal plug, Co Antrim, Northern-Ireland. Journal of Petrology, 23, 427-446.

Sanz, J., Madani, A., Serratosa, J.M, Moya, J.S. and Aza, S. (1988) Aluminium-27 and Silicon-20 MagicAngle Spinning Nuclear Magnetic Resonance study of the kaolinite-mullite transformation. Journal of the American Ceramic Society, 71, 418-421.

Teir, S., Eloneva, S. and Zevenhoven, R. (2005) Reduction of $\mathrm{CO}_{2}$ emissions by calcium carbonate production from calcium silicates, PRES'05, May 1518, 2005, Giardini di Naxos / Messina, Italy. Chemical Engineering Transactions, 7, 571-576.

Toby, B.H. (2001) EXPGUI, a Graphical User Interface for GSAS. Journal of Applied. Crystallography, 34, 210-213.

Tolliday, J.M. (1959) The Crystal Structure of Parawollastonite and Wollastonite. $\mathrm{PhD}$ Thesis, University of London, UK.

Trubnikov, I.L., Solov'ev, L.A. and Lupeiko, T.G. (1989) Synthesis of wollastonite in salt melts, Steklo Keramika, 12, 15-16.

Vakalova, T.V., Pogrebenkov, V.M. and Shlayeva, N.P. (2009) Raw materials effect of structure and 
mineralogical features of silica raw material on phase changes during heating. Refractories and Industrial Ceramics, 50, 18-22.

Vichaphund, S., Kitiwan, M., Atong, D. and Thavorniti, P. (2011) Microwave synthesis of wollastonite powder from eggshells. Journal of the European Ceramic Society, 31, 2435-2440.

Villegas, M.A. and Fernandez Navarro, J.M. (1988) Preparacion y caracterizacion de vidrios del sistema
$\mathrm{CaO}-\mathrm{SiO}_{2}$ por el procedimiento sol-gel, Boletín de la Sociedad Española de Cerámica y Vidrio, 27, 349-357.

Welch, J.H. and Gutt, W. (1959) Tricalcium silicate and its stability within the system $\mathrm{CaO}-\mathrm{SiO}_{2}$. Journal of the American Ceramic Society, 42, 11-15.

Yamanaka, B.T. and Mori, H. (1981) The structure and polytypes of $\alpha-\mathrm{CaSiO}_{3}$ (pseudowollastonite). Acta Crystallographica, 37, 1010-1017. 